\title{
Management Elements for Interpretation Placard System in Mountain Scenic Resort
}

\author{
Hongmei Dong \\ School of Management, Xi' an University of Sciences and Technology \\ Xi'an 710054, China
}

Tel: 86-29-8558-3906 E-mail: donghm_xian@163.com

This work was funded by Shaanxi Education Department (No: 07JK79)

\begin{abstract}
Tourism interpretation placard system is an important carrier conveying information about scenic resort, which can not only serve tourists but also benefit the management. At present, lots of problems exist in mountain scenic resorts' tourism interpretation placard system, which influences the resorts' images and sustainable development. Considering the requirements for interpreting mountain scenic resorts, this paper probes into the management elements for interpretation placard system: establish interpretation placards' locations, contents, and ways in display, and advance to improve the interpretations for natural landscapes, form scientific interpretation views, actualize standardization and characterization of tourism interpretation placard system, and strengthen tourists' safety, with the hope for improving the quality and the utility of constructing mountain scenic resorts' interpretation placard system.
\end{abstract}

Keywords: Mountain scenic resort, Interpretation placard system, Basic element

\section{Introduction}

The word "interpretation" was firstly used in 1871 by John Muir who had lived and worked near Yosemite National Park in USA. In 1957, the father of interpretation Freeman Tilden published Interpreting Our Heritage (Freeman T., 1957), which made interpretation be accepted by the academic field widely. Till after 1964, tourism interpretation got widely recognition and further development (Cho K J., 2005; Ham S H., 2002; Ham S H., 1992). At present, researches and applications concerning tourism interpretation tend to be mature, not only forming a relative perfect specialized system, but also growing into a special interpretation industry that offers services, such as studying, planning, consulting, and training, for tourism interpretation. The service objects cover regions, national parks, history legacies, resorts, geological parks, museums, and institutions (Cho K J., 2005; Ham S H., 2002; Ham S H., 1992; Stewart E J, Hayward B M, Devlin P J, et al., 1998, p257-266; Metro-Roland M., 2009, p270-279). In China researches on tourism interpretation are still at the starting stage (Yongde Zhong \& Fen Luo, 2006, p87-93; Bihu Wu, Xiangping Gao \& Bing Deng, 2003, p326-334), mainly concerning tourism interpretation system's concept, type, theoretical base, relationship of tourism products, tourists behavior, and interpretation service, and discussions on planning of national forest parks, geological parks, and urban parks' tourism interpretation system by cases. All these researches serve as scientific bases for the design and the development of tourism interpretation system in China. However, few researches focus on certain interpretation mode in special.

Placard is an effective tool that can convey tourism information to tourists rapidly and conveniently. It is a popular interpretation mode in tourism interpretation system (Geva A, Goldman A., 1991, p177-185; Zeppel H, Muloin S., 2008, p215-227). An effective interpretation placard system is the best way for scenic resorts without tour guides. But how do we build an effective interpretation placard system? This paper argues that to build a perfect interpretation placard system in mountain scenic resorts is more feasible. China has many mountains. Mountain scenic resorts are tourism hotspots at present in China. However, in many mountain scenic resorts the placard system is imperfect, and interpretation information is incomplete. Besides, the interpretation contents and signals are not in accordance with standards. Furthermore, there is not placard at all. All these problems are rooted in the management of placard system. Therefore, to enhance the management on the interpretation placard system in mountain scenic resorts is extremely important. This paper advances some basic elements for the interpretation placard system in mountain scenic resorts, and puts forward several problems in management, with the hope of supplying valuable references for the construction of tourism interpretation placard system. 


\section{Basic requirements for tourism interpretation system in mountain scenic resorts}

\subsection{Give prominence to the geological and seasonal beauty of mountain scenic resorts}

Tourism interpretation should give prominence to the aesthetic value of landscapes. The unique feature of mountain scenic resorts is the geological and seasonal beauty. Generally speaking, human activities are mostly in valleys, piedmonts, and low mountains, where the agriculture and livestock industries are relatively developed, displaying an agricultural and livestock culture. Go upward and human activities are less. Many rare animals and plants live there, displaying a typical natural scene. If the mountain is high, it will show an evident vertical zonality view. All these scenes display the geological beauty of mountain scenic resorts. Besides, waters, weathers, and biology in mountain scenic resorts change seasonally. Tourism interpretation should emphasize this point, which can help tourists understand and appreciate the beauty of mountain scenic resorts completely.

\subsection{Combine mountain scenic resorts' normal interpretation and special interpretation together}

Mountain scenic resorts include geological appearance, weather and climate, waters, animals and plants, where the tourism development needs normal comprehensive projects and lines, and special tourism projects. Therefore, in designing specific tourism interpretation, both normal comprehensive interpretation and special scientific interpretation are necessary in order to satisfy all tourists' needs and choices.

\subsection{Give prominence to the interpretation of ecological value}

Mountains in China are important water sources, where many wild animals and plants live. However, most mountain ecological systems are incapable of self-adjustment. Any over- or irrational exploration will destroy the scenic resorts: the living spaces for animals and plants are ruined, which may cause the decline of mountain ecological system, or even make it collapse completely. Therefore, at the typical ecological scenic zone, the environment-sensitive zone, and ecology-fragile zone, it is necessary to build placards with clear ecological interpretation contents and environment protection, which can mention tourists to behave themselves as they appreciate mountains' natural and cultural scenes.

\section{Management elements for mountain scenic resorts' tourism interpretation placard system}

\subsection{Collect relevant basic data}

To manage the tourism interpretation placard system, we should collect some basic data concerning tourism resources, ecological system, infrastructure, and tourist management. Besides, pay attention to the latest researches on relevant fields and update related data in time. However, due to the complexity of mountain resources and environment, relevant data or information may separate at different levels. In detain, see to Table 1 as follow.

In addition, mountains at different climate zones have unique seasonal scenes. However, at present the descriptions about seasonal environment in mountain scenic resorts are rough and even similar, such as "distinct seasons, pleasant climate, prosperous flowers in spring, heavy shadow in summer, red leafage in autumn, and white trees in winter". These seasonal descriptions can not help tourists understand the unique seasonal differences at various mountain scenic resorts. Besides, mountain climate changes vertically. The so-called "four seasons in one mountain and different weathers in ten miles" is a typical summarization. Therefore, as for what seasonal scenes appear at what time and where, a relevant interpretation system is necessary (see Table 2).

\subsection{Establish the location of placards}

Landscapes in mountain scenic resorts change along with the contour line. At different altitudes, climate landscapes, vegetation landscapes, geological landscapes are different sharply. At the same altitude, climate landscapes and vegetation landscapes are similar. Therefore, in mountain scenic resorts, we can select interpretation locations and build sightseeing stands and interpretation placards according to changes of landscapes vertically. Following the contour line, construct circular touring lines at the same forest belt and climate zone and build sightseeing stands and interpretation placards. Build circular touring lines and interpretation placards in virgin forest. Select sightseeing stands with rare animals and plants and build interpretation placards. Build sightseeing stands and interpretation placards in alpine meadow or wild flowers areas. Construct touring lines, sightseeing stands and interpretation placards in special geological sightseeing belts.

Establish locations that need to be protected in special, such as some ecological environment place, special landscapes, areas with rare animals and plants. Set placards and use simple words or signals to mention tourists to behave themselves, in case of disturbing animals' activities, or destroying plants, or affecting the environments in landscapes. Set safety marks for dangerous roads, waters, animals, weathers, and plants, and make explanations for prevention. Set warning marks for roads where the traffic is terrible in order to call attention to potential dangers. In the area with potential threats, put clear warnings for real conditions and forbid tourists to enter.

\subsection{Establish the contents of placards}

In designing the contents of placards, the management of infrastructure and tourists safety is relatively easy. According 
to China's Graphical Symbols for Use on Public Information Signs (GB/T10001.1-2000), design placards with legal signals, styles, and colors. But concerning the attractive environment, the contents of placards should be scientific and complete. Too much or too less is unsatisfied. As build interpretation placards in mountain scenic resorts and landscapes, we can integrate the interpretation of sources and that of environment together in order to help tourists form a general recognition to the resorts or landscapes. The placards should be larger and contents should be general. In these landscapes, basic types of resources (exclude comprehensive resorts) consume most time of tourists, which is the key in designing interpretation placards. However, at present the interpretation for this part is poor. Most placards merely present the names, which can not help tourists appreciate the value of resorts. Therefore, on one hand we should set independent interpretation placards, presenting scientific names and explanations. On the other hand, we should make further studies on the specific contents and lengths of interpretation.

\subsection{Choose the display manner of placards}

At present, placards are mainly displayed statistically, not matter what it concerns content or form. This paper suggests new display manners, such as noiseless circular ads placards used frequently by outdoor ads and electric ads placards with sounds and colors. We can apply these new manners to the design of tourism interpretation placards, which can effectively improve the attractiveness of interpretation placards. However, the costs for these new tourism placards are higher. At present, we can make experiments in areas with developed tourism and economy or world legacy areas.

\section{Problems for building tourism interpretation placard system in mountain scenic resorts}

\subsection{Reform traditional tourism interpretation that neglects natural touring landscape but emphasizes on humanism landscape}

Traditional tourism managers hold an idea that humanism landscape has rich cultural meanings and deserves to be interpreted but natural landscape has no deep meanings and tourists can appreciate natural landscape by themselves. As a result, we seldom see perfect interpretation placards in natural landscapes. Surely, humanism landscape has rich cultural meanings. But natural landscape also has rich scientific meanings. To interpret the natural landscape is not easier than the humanism landscape. Especially in ecological tourism resorts, an interpretation system is inevitable in order to help tourists appreciate the secrets of the nature really. Therefore, it is urgent to change the traditional bias to tourism interpretation that neglects the interpretation for natural tourism landscapes and emphasizes on the interpretation for humanism landscapes.

\subsection{Build a scientific interpretation view for natural landscape, instead of the so-called "fairy tales" or "stories".}

Presently, many interpretations for mountain scenic resorts in China, especially for the water landscape and geological landscape, are about stories and fairy tales. They seldom concern the scientific meanings. It is not in accordance with the aim of ecological tourism and may affect the sustainable development of tourism industry in an area. Therefore, we must build a scientific interpretation view for natural landscape, instead of the so-called "fairy tale" or "stories".

\subsection{Actualize the standardization and characterization of tourism interpretation placard system}

The design of interpretation placard system for resorts' infrastructure includes materials, forms, colors, and words. Maintain the standardization as much as possible. Tourists can recognize them easily. The design of interpretation placard system for resorts and landscapes should reflect local features, which can deepen the memory of tourists. In order to actualize the characterization, we can use local materials for placards. And the shape and color of placards should be in accordance with the resorts. In other words, the shape and the color of placards match with the target in interpretation. For example, man-made stones far away from landscape can adopt "micro" landscape as patterns in placards. By this way, tourists can appreciate the landscape in a short distance. Besides, it increases the experience value of placard system.

\subsection{Strengthen the construction of interpretation placards for the safety of tourists}

The diversity of mountain scenic resorts makes it turn into the best place for ecological tour and exploration tour. However, because mountains are full of horizontal zones and vertical belts, geology, climate, soil, and biological group change significantly in a short distance or a narrow space. Mountains are dangerous, where accidents happen frequently. Therefore, we should strengthen the interpretation for the safety of tourists.

\section{References}

Cho K J. (2005). Developing all interpretive planning model for a national park system: stakeholder-based needs assessment study for Korea. Columbus: The Ohio State University.

Freeman T. (1957). Interpreting Our Heritage. Chapel Hill, NC: University of North Carolina Press.

Geva A, Goldman A. (1991). Satisfaction measurement in guided tours. Annals of Tourism Research, No.18(2), p.177-185.

Ham S H. (1992). Environmental interpretation-A practical guide for people with big ideas and small budgets. Golden, 
Colorado: North American Press.

Ham S H. (2002). A Perspective on the Evolution of Interpretive Research. Taiwan, US, and Australia International Symposium on Environmental Interpretation and Ecotourism Taichung, Taiwan.

Metro-Roland M. (2009). Interpreting Meaning: An application of Peircean Semiotics to Tourism. Tourism Geographies, No.11, p. 270-279.

Stewart E J, Hayward B M, Devlin P J, et al. (1998). The "place" of interpretation: a new approach to the evaluation of interpretation. Tourism Management, No. 19. P. 257-266.

$\mathrm{Wu}$, Bihu. Gao, Xiangping \& Deng, Bing. (2003). Progress in environmental interpretation: A literature review. Progress in Geography, No. 22(3), p. 326-334.

Zeppel H, Muloin S. (2008). Conservation and education benefits of interpretation on Marine Wildlife Tours. Tourism in Marine Environments, No. 5, p. 215-227.

Zhong, Yongde \& Luo, Fen. (2006). A literature review of tourism interpretation. World Regional Studies, No. 15(4), p. 87-93.

Table 1. The basic data of tourism interpretation in Mountain Scenic Resort

\begin{tabular}{|c|c|c|c|}
\hline & \multicolumn{3}{|l|}{ Basic data } \\
\hline & Large spatial scope & Middle spatial scope & Small spatial scope \\
\hline $\begin{array}{l}\text { Interpretation for } \\
\text { tourism resources }\end{array}$ & $\begin{array}{l}\text { Tourism resorts' main class, } \\
\text { subclass, features, distribution, } \\
\text { main scenic areas' } \\
\text { distribution, features, and } \\
\text { travel lines' type and features }\end{array}$ & $\begin{array}{l}\text { Subclass resorts' types, } \\
\text { distribution and features, } \\
\text { causes, internal nature, } \\
\text { scientific values and } \\
\text { meanings, entertainment } \\
\text { values, medical values, } \\
\text { ecological values, main } \\
\text { tourism sights and } \\
\text { projects }\end{array}$ & $\begin{array}{l}\text { Resource unit's } \\
\text { aesthetic features and } \\
\text { appreciation values, } \\
\text { including beauty of } \\
\text { shape, beauty of } \\
\text { colors, beauty of } \\
\text { rareness, beauty of } \\
\text { uniqueness, beauty of } \\
\text { smell, beauty of sound, } \\
\text { and beauty of change }\end{array}$ \\
\hline $\begin{array}{l}\text { Interpretation for } \\
\text { ecological system }\end{array}$ & $\begin{array}{l}\text { Ecological feature: climate, } \\
\text { geology, water, community, } \\
\text { type of ecological system, and } \\
\text { the spatial distribution } \\
\text { Environment feature: spatial } \\
\text { distribution of soil erosion, } \\
\text { garbage pollution, water } \\
\text { quality, soil pollution, air } \\
\text { pollution, noise pollution, } \\
\text { biodiversity, sorts of pollutants }\end{array}$ & 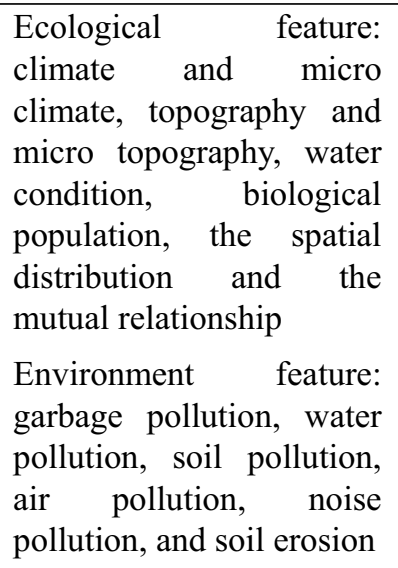 & $\begin{array}{l}\text { Typical micro climate, } \\
\text { micro topography, } \\
\text { stone, soil, water, } \\
\text { biological individual } \\
\text { and population's } \\
\text { physiological and } \\
\text { ecological features }\end{array}$ \\
\hline $\begin{array}{l}\text { Interpretation for } \\
\text { infrastructure }\end{array}$ & \multicolumn{3}{|c|}{ Facilities for transportation, board and lodging, and emergency } \\
\hline $\begin{array}{l}\text { Interpretation for } \\
\text { tourist } \\
\text { management }\end{array}$ & \multicolumn{3}{|c|}{$\begin{array}{l}\text { Conditions for ecological frangibility and environmental sensitiveness, and the } \\
\text { distribution, threats and the distribution in mountain scenic resorts }\end{array}$} \\
\hline
\end{tabular}


Table 2. The basic data of season environment interpretation in Mountain Scenic Resort

\begin{tabular}{|l|l|l|l|}
\hline Season & Climate data & $\begin{array}{l}\text { Landscapes' seasonal features and data for symbolizing } \\
\text { seasonal landscape }\end{array}$ & $\begin{array}{l}\text { Goals } \\
\text { interpreting } \\
\text { environments at } \\
\text { different seasons }\end{array}$ \\
\hline $\begin{array}{l}\text { Spring } \\
\text { Summer }\end{array}$ & $\begin{array}{l}\text { Every season's } \\
\text { time period, air } \\
\text { temperature, } \\
\text { Autumn } \\
\text { Winter } \\
\text { humidity, wind, } \\
\text { snow, and fog }\end{array}$ & $\begin{array}{l}\text { Interpret the environmental features of resorts at } \\
\text { different seasons, point out the symbolizing landscapes } \\
\text { at different seasons, including typical trees and grasses, } \\
\text { and their germination period, green leaves period, } \\
\text { florescence, fruit period, maturity period, leaves } \\
\text { changing period, and abscission period. Biological stage } \\
\text { indicates certain season. }\end{array}$ & $\begin{array}{l}\text { symbolizing } \\
\text { locations for } \\
\text { and seasons } \\
\text { interpretation build } \\
\text { placard system }\end{array}$ \\
\hline
\end{tabular}

